\title{
Sistem Prediksi Jumlah Permintaan Produk Darah Menggunakan Metode Least Square Regression Line (Studi Kasus : Utd Pmi Kabupaten Jombang)
}

\author{
Dzurrotun Nasyika*, Slamin**, Priza Pandunata *** \\ * Student at University of Jember, ** Lecture at University of Jember, \\ $* * *$ Lecture at University of Jember \\ * dnasyika@gmail.com, ${ }^{* *}$ Slamin@unej.ac.id, \\ *** Priza@unej.ac.id,
}

\begin{abstract}
ABSTRAK
Blood Transfusion Unit (UTD) as the provider of blood supply is required to fulfill blood demand. However in reality, the blood stock does not always meet the demand for blood. The amount of blood group stock in UTD depends on blood donors who voluntarily donate blood. Red blood cells only have a life span of 35 days since they were donated, if they have passed that time the blood cannot be used for transfusion. Based on these problems, the authors applied the Lesat Square Regression Line method to predict the number of requests for blood products in the coming month. The calculation results obtained prediction of demand with the smallest MAPE value that is blood product of PRC blood type A with a value of $14.40 \%$. The biggest MAPE value obtained is $180.66 \%$ for WB blood type AB. Factors or parameters that affect the amount of blood product demand, that is the environment, disease outbreaks and differences in body resistance of each blood group. In addition, the types of blood products also have a number of different requests depending on the level of blood needs for health.
\end{abstract}

Kata Kunci: Peramalan, Least Square Regression Line, PMI, Produk Darah

\section{Pendahuluan}

Unit Transfusi Darah (UTD) sebagai penyelenggara penyediaan darah dituntut untuk memenuhi permintaan darah pada daerahnya masing-masing. Namun pada kenyataannya, stok darah yang terdapat pada tiap daerah tidak selalu memenuhi kebutuhan permintaan darah. Jumlah stok golongan darah pada UTD bergantung oleh pendonor darah yang secara sukarela mendonorkan darahnya. Sel darah merah hanya memiliki masa hidup 35 hari sejak didonorkan, jika sudah melewati rentang waktu tersebut maka darah sudah tidak boleh lagi digunakan untuk transfusi [1]. Hal ini yang menjadi hambatan pada UTD PMI Kabupaten Jombang dalam mengontrol persediaan stok golongan darah yang tidak sesuai dengan permintaan darah di Kabupaten Jombang.

Berdasarkan semua data yang tersedia, pengelola pusat penyimpanan darah memiliki tugas penting, yakni memperkirakan kebutuhan komponen darah untuk meminimalisir penuhnya penyimpanan maupun kerugian karena darah yang terbuang [2]. Kurangnya pasokan dapat berdampak pada meningkatnya jumlah kematian pasien. Di sisi lain, berlebihnya pasokan darah hingga melewati masa simpannya juga tidak seharusnya terjadi, karena pendonor darah merupakan aset langka yang dibatasi waktu untuk mendonorkan darahnya [3]. Untuk mengantisipasi masalah tersebut diperlukan perencanaan pada pihak UTD yang mampu memperkirakan permintaan produk darah pada bulan selanjutnya, sehingga kebutuhan darah dapat dipenuhi dengan efisien.

Data permintaan darah yang ada di UTD PMI Kabupaten Jombang dapat digunakan sebagai bahan untuk memprediksi permintaan produk darah pada bulan berikutnya. Untuk saat ini UTD PMI Kabupaten Jombang dalam melakukan strategi untuk memprediksi permintaan produk darah selanjutnya hanya menggunakan data sebelumnya tanpa adanya sistem yang melakukan peramalan (dilakukan secara manual). Dalam hal ini cara yang dapat dilakukan untuk memprediksi jumlah permintaan produk darah secara cepat dan efisien agar memudahkan pihak UTD adalah dengan membangun sebuah Sistem Prediksi Permintaan Produk Darah Menggunakan Metode Least Square Regression Line.

\section{Metode Penelitian}


Jenis Penelitian

Jenis penelitian yang dilakukan adalah penelitian kualitatif dan kuantitatif. Penelitian kuantitatif adalah penelitian ilmiah yang sistematis terhadap bagian-bagian dan fenomena serta hubunganhubungannya. Sedangkan penelitian kualitatif adalah penelitian ilmiah yang memfokuskan pada pemahaman fenomena sosial dari sudut pandang partisipan secara deskriptif.

\section{Tempat dan Waktu Penelitian}

Penelitian ini dilakukan di UTD PMI Kabupaten Jombang yang beralamatkan di Jalan KH. Wahid Hasyim No. 133, Kepanjen, Jombang, Kepanjen, Kec. Jombang, Kabupaten Jombang. Penelitian dilakukan selama 4 bulan yaitu dari bulan Desember 2017 sampai Maret 2018.

\section{Tahap Pengembangan}

Metode pengembangan yang digunakan adalah System Development Life Cycle (SDLC) dengan menggunakan model waterfall. Model waterfall digunakan karena kualitas sistem dari model ini cenderung baik yang disebabkan tahapannya terstruktur dan sequential. Setiap aktivitas pada model pengembangan waterfall harus diselesaikan sebelum menuju tahap pengembangan selanjutnya.

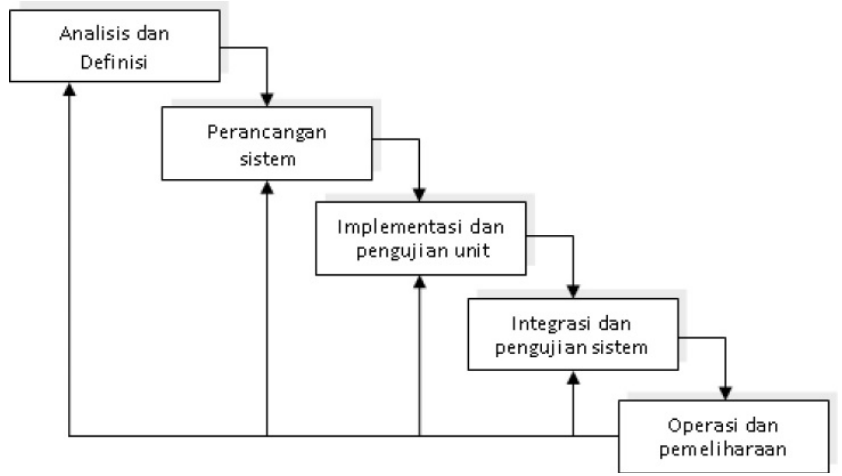

Gambar 1 Model Waterfall

\section{a. Analisa Kebutuhan}

- Pengumpulan Data

- Data Primer

Data Primer merupakan data yang dikumpulkan secara langsung dari objek yang diteliti. Dalam pengumpulan data primer terdapat dua metode yaitu metode observasi dan metode wawancara (interview) yang akan dilakukan di UTD PMI Kabupaten Jombang. Wawancara ini dilakukan secara langsung dengan pimpinan dan pegawai untuk mengetahui jumlah permintaan produk darah.

- Data Sekunder

Data skunder merupakan data yang dikumpulkan dari study literatur pada penelitianpenelitian terdahulu di berbagai jurnal, buku,skripsi, dan e-book. Study literatur digunakan untuk menunjang pemahaman dan pengetahuan penulis tentang materi, konsep, teori, dan metode yang dibutuhkan dalam proses pengerjaan tugas akhir.

- $\quad$ Analisis Data

Penyelesaian masalah menggunakan metode Least Square Regression Line untuk memudahkan pemahaman dan alur proses yang akan dibahas. 


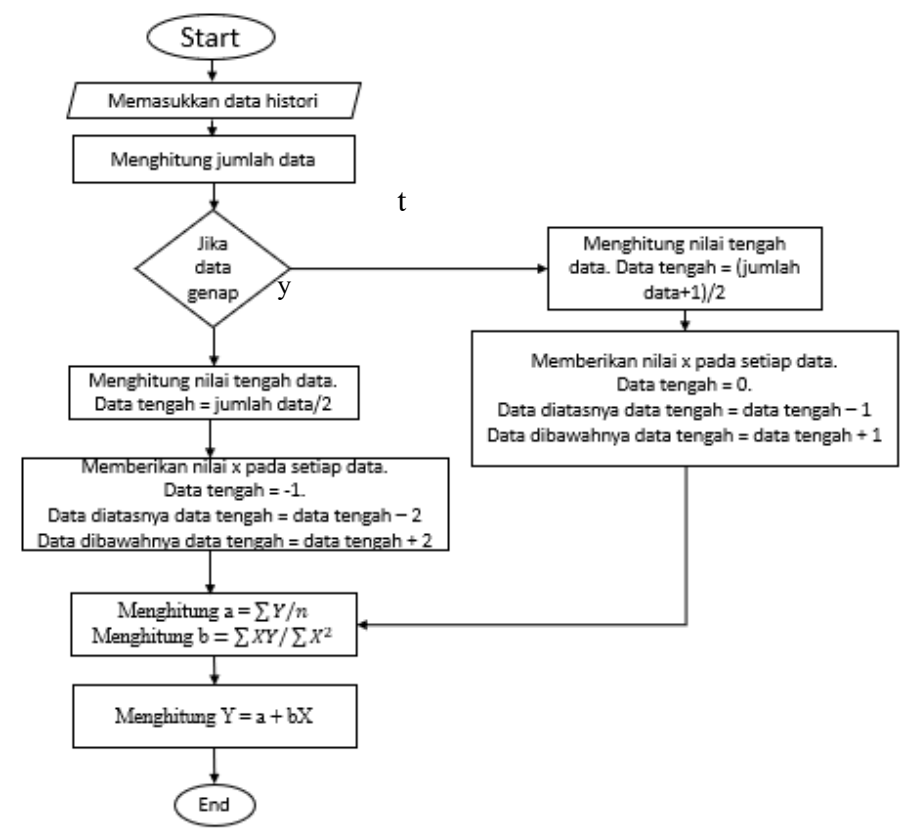

Gambar 2 Diagram Blok Perhitungan Metode Least Square

b. Desain

Pembuatan desain sistem pada penelitian ini menggunakan Unified Modeling Language (UML) yang dirancang dengan konsep Object Oriented Design. Permodelan UML yang digunakan adalah sebagai berikut :

1. Elemen Input dan Output Sistem

2. Usecase Diagram

3. Scenario

4. Sequence Diagram

5. Activity Diagram

6. Class Diagram

7. Entity Relationship Diagram

c. Implementasi

Dari desain yang telah dibuat akan diimplementasikan ke dalam kode program. Hal yang dilakukan dalam tahap implementasi antara lain:

- Penulisan kode program (coding) menggunakan bahasa pemrograman Page Hyper Text PreProcessor (PHP) dengan bantuan framework Laravel.

- Manajemen basisdata menggunakan MySQL.

- Tampilan berbasis website.

d. Pengujian

- White box testing

White box testing adalah pengujian yang didasarkan pada pengecekan terhadap detail perancangan, menggunakan struktur kontrol dari desain program secara procedural untuk membagi pengujian ke dalam beberapa kasus pengujian.

- Black box testing

Black box testing adalah pengujian yang dilakukan hanya mengamati hasil eksekusi melalui data uji dan memeriksa fungsional dari perangkat lunak.

e. Pemeliharaan

Perangkat lunak yang sudah selesai akan mengalami perubahan. Perubahan biasanya berupa error sehingga diperlukan perbaikan dan pemeliharaan kepada sistem. 
Pengembangan sistem dalam penelitian ini meliputi, analisis kebutuhan dan desain sistem.

\section{Analisis Kebutuhan}

Analisa kebutuhan menggunakan hasil dari pengumpulan dan analisa data yang telah didapatkan sebagai dasar menentukan kebutuhan sistem prediksi permintaan produk darah menggunakan metode least square regression line yang akan dibangun. Kebutuhan-kebutuhan sistem tersebut dibagi menjadi kebutuhan fungsional dan kebutuhan non-fungsional yang menjelaskan hal-hal yang dapat dilakukan oleh sistem.

Kebutuhan fungsional pada penelitian ini sebagai berikut :

1. Sistem dapat mengelola data user

2. Sistem dapat mengelola data stok darah

3. Sistem dapat mengelola data permintaan darah

4. Sistem dapat mengelola data pendonor

5. Sistem dapat mengelola data transaksi donor darah

6. Sistem dapat mengelola data ramalan permintaan darah

7. Sistem dapat melihat MAPE hasil ramalan

Kebutuhan non-fungsional pada penelitian ini yaitu sistem menggunakan username dan password sebagai autentifikasi akses terhadap sistem.

\section{Desain Sistem}

Desain sistem meliputi Elemen Input dan Output Sistem, use case diagram, dan Entity Relationship Diagram (ERD). Elemen Input dan Output Sistem adalah suatu kumpulan aktivitas yang terstruktur untuk mencapai suatu tujuan tertentu atau untuk menghasilkan sebuah produk. Ada beberapa komponen di dalamnya, meliputi data yang menjadi masukan (input), data masukan yang kemudian diolah menjadi data keluaran (output), media yang digunakan (uses), dan tujuan yang ingin dicapai (goal). Elemen Input dan Output Sistem aplikasi ini dapat dilihat pada Gambar 3.

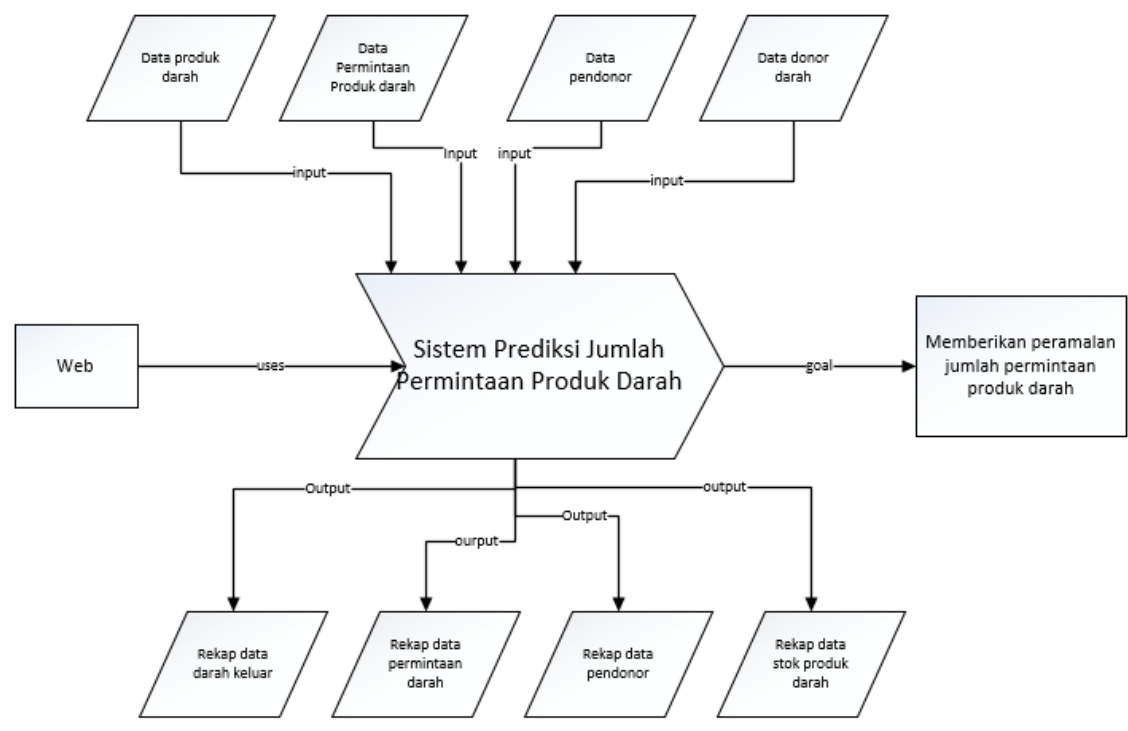

Gambar 3 Elemen Input dan Output Sistem

Usecase diagram merupakan gambaran interaksi antara aktor yang terlibat dalam sistem dengan fitur sistem informasi peramalan jumlah permintaan darah yang dibuat untuk memenuhi kebutuhan fungsional dan non-fungsional sistem. Use Case Diagram aplikasi ini dapat dilihat pada Gambar 4. 


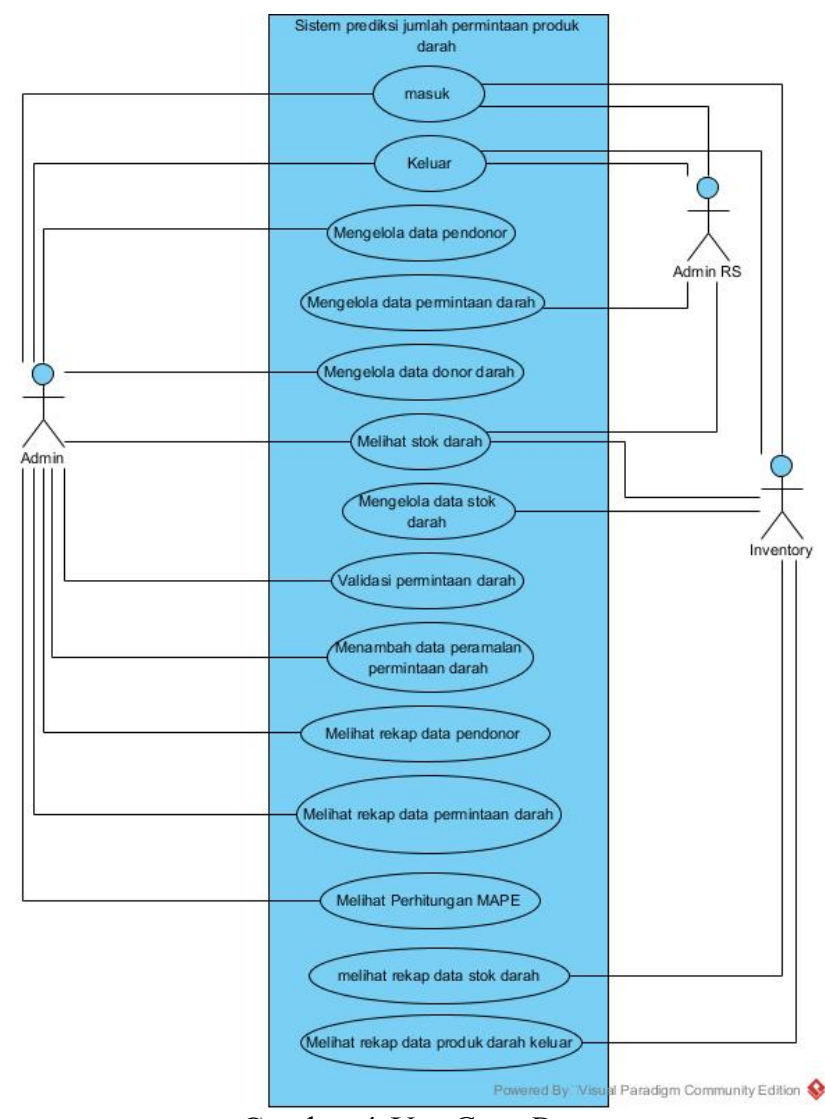

Gambar 4 Use Case Diagram

Entity Relationship Diagram (ERD) menjelaskan hubungan antar data dalam database yang digunakan dalam pembangunan sistem. ERD aplikasi ini dapat dilihat pada Gambar 5.
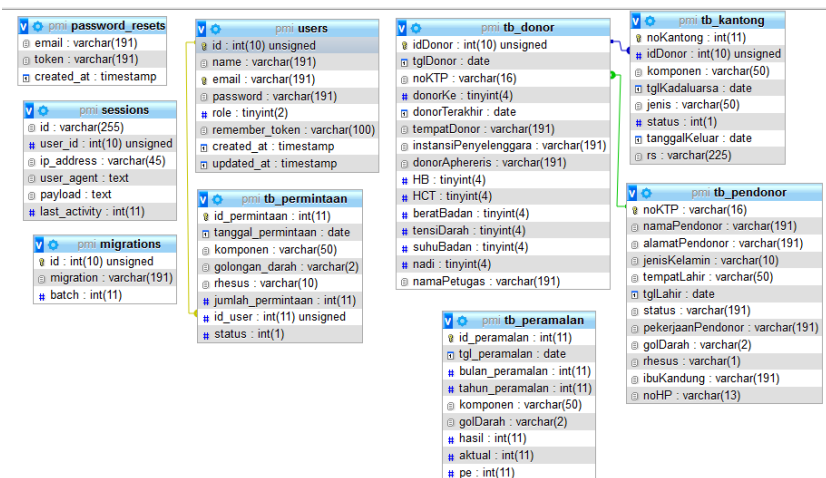

Gambar 5 Entity Relationship Diagram

\section{Hasil dan Pembahasan}

\subsection{Hasil Perhitungan Metode Least Square}

Perhitungan metode least square ini menggunakan data aktual permintaan produk darah pada bulan Januari 2017 sampai Oktober 2018. Rumus dalam perhitungan metode ini terdapat pada persamaan 1 sampai 3 berikut.

$$
\begin{array}{r}
Y=a+b X \\
\text { Dimana }: \\
a=\frac{\sum Y}{n} \\
b=\frac{\sum X Y}{\sum X^{2}}
\end{array}
$$

Keterangan : 
$\mathrm{X}=$ periode (waktu)

$\mathrm{Y}=$ jumlah permintaan pada periode $\mathrm{X}$

$\mathrm{a}=$ bilangan konstan

$\mathrm{b}=$ koefisien kecondongan garis tren

$\mathrm{n}=$ jumlah data

Berikut sampel perhitungan baris terakhir peramalan beserta MAPE pada Tabel 1.

\begin{tabular}{|c|c|c|c|c|c|}
\hline No & Produk & Golongan Darah & Ramalan & Aktual & MAPE \\
\hline 1. & WB & A & 74 & 62 & 19,78 \\
\hline 2. & WB & B & 80 & 69 & 19,73 \\
\hline 3. & WB & $\mathrm{AB}$ & 15 & 11 & 180,66 \\
\hline 4. & WB & $\mathrm{O}$ & 100 & 79 & 27,20 \\
\hline 5. & PRC & $\mathrm{A}$ & 183 & 178 & 14,40 \\
\hline 6. & PRC & B & 285 & 277 & 15,23 \\
\hline 7. & PRC & $\mathrm{AB}$ & 63 & 41 & 31,40 \\
\hline 8. & PRC & $\mathrm{O}$ & 454 & 379 & 16,32 \\
\hline 9. & $\mathrm{TC}$ & A & 22 & 18 & 103,99 \\
\hline 10. & TC & B & 33 & 38 & 98,64 \\
\hline 11. & TC & $\mathrm{AB}$ & 6 & 7 & 39,77 \\
\hline 12. & $\mathrm{TC}$ & $\mathrm{O}$ & 46 & 56 & 46,01 \\
\hline 13. & LP & A & 2 & 1 & 52,92 \\
\hline 14. & LP & B & 1 & 2 & 45,83 \\
\hline 15. & LP & $\mathrm{AB}$ & 1 & 1 & 30,83 \\
\hline 16. & LP & $\mathrm{O}$ & 3 & 4 & 94,24 \\
\hline 17. & FFP & A & 2 & 2 & 45,42 \\
\hline 18. & FFP & B & -1 & 1 & 135,56 \\
\hline 19. & FFP & $\mathrm{AB}$ & 1 & 1 & 17,50 \\
\hline 20. & FFP & $\mathrm{O}$ & 2 & 8 & 90,46 \\
\hline
\end{tabular}

Hasil dari perhitungan manual dan perhitungan pada sistem memliki nilai yang sama.

\subsection{Hasil Pembangunan Sistem}

Sistem prediksi jumlah permintaan produk darah menggunakan metode Least Square Regression Line memiliki beberapa fitur. Terdapat tiga hak akses pada sistem ini, yaitu admin yang mempunyai hak akses penuh terhadap sistem, bagian inventory yang mempunyai hak akses terbatas, dan admin bank darah yang terdapat di rumah sakit. Berikut penjelasan mengenai fitur-fitur yang terdapat pada sistem prediksi jumlah permintaan produk darah:

\section{Halaman landing}

Halaman landing merupakan halaman awal ketika user mengakses sistem. Pada halaman ini terdapat tombol login yang nanti akan diarahkan ke halaman selanjutnya jika akan memasuki sistem. Tambilan halaman landing dapat dilihat pada gambar 6 berikut. 


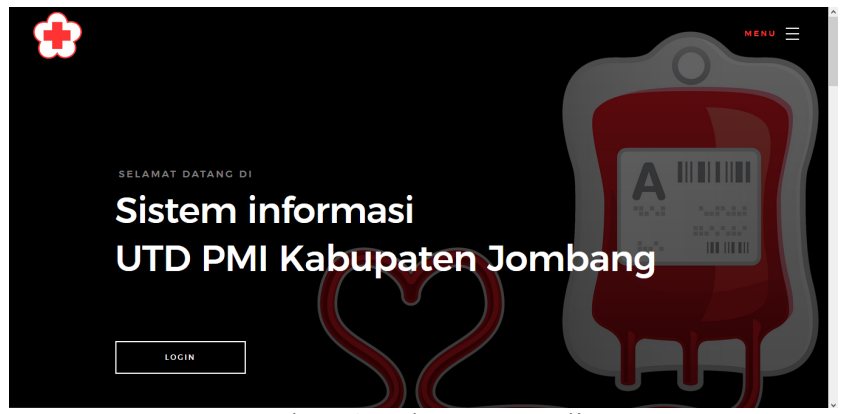

Gambar 6 Halaman Landing

\section{Halaman Masuk Sistem}

Fitur ini merupakan fitur autentifikasi pengguna untuk dapat masuk kedalam sistem dan mengakses fiturfitur sesuai hak aksesnya. Pengguna dapat mengisikan email dan password untuk masuk ke dalam sistem. Tampilan halaman masuk sistem dapat dilihat pada gambar 7.

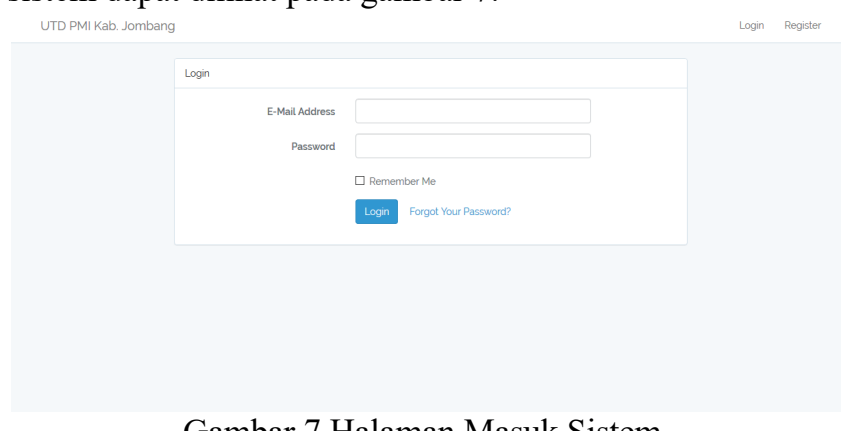

Gambar 7 Halaman Masuk Sistem

3. Fitur mengelola data permintaan darah

Fitur ini berfungsi untuk mengelola permintaan darah yaitu melihat dan menambah data permintaan darah ke PMI. Fitur ini hanya dapat diakses oleh admin bank darah rumah sakit. Tampilan halaman mengelola permintaan darah dapat dilihat pada gambar 8 .

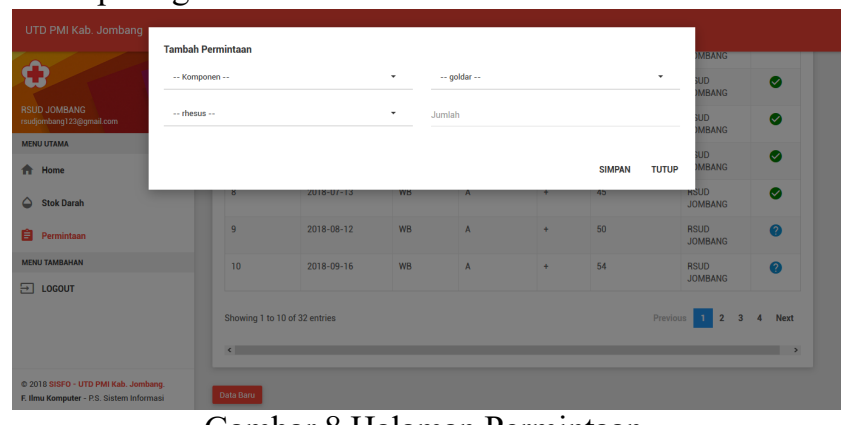

4. Fitur validasi permintaan darah

Fitur ini berfungsi untuk memvalidasi permintaan yang dilakukan oleh admin bank darah rumah sakit. Tampilan halaman validasi permintaan darah dapat dilihat pada gambar 9.

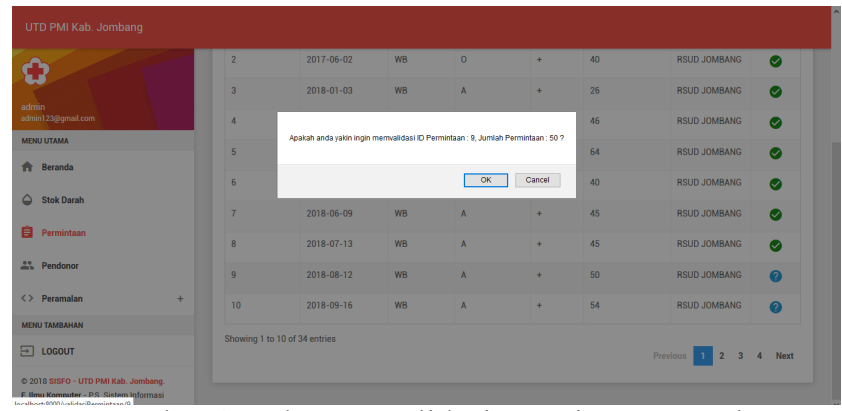

Gambar 9 Halaman Validasi Permintaan Darah 
5. Fitur menambah data peramalan permintaan darah

Fitur ini berfungsi untuk mengelola peramalan yang meliputi melihat dan menambah peramalan permintaan darah. Tampilan halaman kelola peramalan dapat dilihat pada gambar 10 .

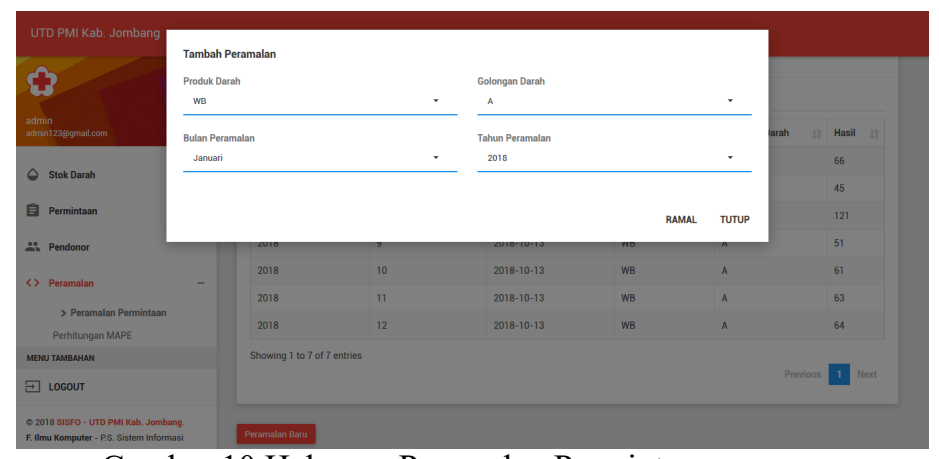

Gambar 10 Halaman Peramalan Permintaan

\section{Kesimpulan dan Saran}

\section{Kesimpulan}

Kesimpulan dari penelitian yang dilakukan adalah:

a. Metode Least Square digunakan untuk menghitung nilai prediksi jumlah permintaan produk darah. Dari hasil perhitungan didapatkan prediksi permintaan dengan nilai MAPE terkecil yaitu produk darah PRC golongan A dengan nilai 14,40\%. Nilai MAPE terbesar yang diperoleh yaitu 180,66\% untuk WB golongan AB.

b. Hasil perhitungan sistem menunjukkan nilai yang sama dengan perhitungan manual, sehingga sistem prediksi menggunakan metode Least Square Regression Line dapat digunakan untuk memprediksi jumlah permintaan produk darah pada UTD PMI Kabupaten Jombang.

c. Faktor atau parameter yang mempengaruhi jumlah permintaan produk darah yaitu lingkungan, wabah penyakit dan perbedaan daya tahan tubuh tiap golongan darah. Selain itu jenis produk darah juga memiliki jumlah permintaan yang berbeda bergantung dengan tingkat kebutuhan darah untuk kesehatan.

\section{Saran}

Saran yang ditujukan untuk memberikan masukan yang lebih baik yaitu :

a. Prediksi jumlah permintaan produk darah dapat dilakukan dengan menggunakan metode lain atau dapat dilakukan dengan rentang waktu yang berbeda misalnya harian.

b. Sistem prediksi jumlah permintaan produk darah dapat dikembangkan lagi menjadi sistem informasi yang lebih besar lagi agar dapat mengelola berbagai informasi dan berguna untuk masyarakat umum tidak hanya pihak rumah sakit dan PMI saja.

\section{Daftar Pustaka}

[1] Rutherford, C., Cheng, S. Y., \& Bailie, K. (2016). Evidence of Bullwhip in the Blood Supply Chain. HeriotWatt University Research Gateway.

[2] Filho, O., Cezarino, W., \& Salviano, G. (2012). A Decision-making Tool for Demand Forecasting of Blood Components. Science Direct, 1499-1504.

[3] Belien, J., \& Force, H. (2012). Supply Chain Management of Blood Products. European Journal of Operational Research, 1-16. 